Article

\title{
Accumulation, Biotransformation, Histopathology and Paralysis in the Pacific Calico Scallop Argopecten ventricosus by the Paralyzing Toxins of the Dinoflagellate Gymnodinium catenatum
}

\section{Amada Y. Escobedo-Lozano ${ }^{1,2}$, Norma Estrada ${ }^{3,4}$, Felipe Ascencio ${ }^{4}$, Gerardo Contreras ${ }^{3}$ and Rosalba Alonso-Rodriguez ${ }^{1, *}$}

1 Laboratorio de Biotoxinas Marinas, Instituto de Ciencias del Mar y Limnologia, Universidad Nacional Autonoma de Mexico, Apdo. Postal 811, Mazatlan, Sinaloa 82040, Mexico; E-Mail: amadayerene@yahoo.com.mx

2 Departamento de Ingenieria Quimica-Bioquimica, Instituto Tecnologico de Mazatlan, Calle Corsario 1 No. 203, Col. Urias, Mazatlan, Sinaloa 82070, Mexico

3 Departamento de Fisiologia, Biofisica y Neurociencias, Centro de Investigacion y de Estudios Avanzados del IPN, Av. Instituto Politecnico Nacional 2508, Mexico City, D.F. 07300, Mexico; E-Mails: normaestrada9@gmail.com (N.E.); rcontrer@fisio.cinvestav.mx (G.C.)

4 Departamento de Patologia Marina, Centro de Investigaciones Biologicas del Noroeste, Mar Bermejo 195, Col. Playa Palo de Santa Rita, La Paz, B.C.S. 23096, Mexico; E-Mail: ascencio@cibnor.mx

* Author to whom correspondence should be addressed; E-Mail: rosalba@ola.icmyl.unam.mx; Tel.: +52-669-985-2845; Fax: +52-669-982-6133.

Received: 1 March 2012; in revised form: 10 April 2012 / Accepted: 18 April 2012 / Published: 9 May 2012

Abstract: The dinoflagellate Gymnodinium catenatum produces paralyzing shellfish poisons that are consumed and accumulated by bivalves. We performed short-term feeding experiments to examine ingestion, accumulation, biotransformation, histopathology, and paralysis in the juvenile Pacific calico scallop Argopecten ventricosus that consume this dinoflagellate. Depletion of algal cells was measured in closed systems. Histopathological preparations were microscopically analyzed. Paralysis was observed and the time of recovery recorded. Accumulation and possible biotransformation of toxins were measured by HPLC analysis. Feeding activity in treated scallops showed that scallops produced pseudofeces, ingestion rates decreased at $8 \mathrm{~h}$; approximately $60 \%$ of the scallops were paralyzed and melanin production and hemocyte aggregation were observed in several tissues at $15 \mathrm{~h}$. HPLC analysis showed that the only toxins present in the dinoflagellates 
and scallops were the $N$-sulfo-carbamoyl toxins (C1, C2); after hydrolysis, the carbamate toxins (epimers GTX2/3) were present. $\mathrm{C} 1$ and $\mathrm{C} 2$ toxins were most common in the mantle, followed by the digestive gland and stomach-complex, adductor muscle, kidney and rectum group, and finally, gills. Toxin profiles in scallop tissue were similar to the dinoflagellate; biotransformations were not present in the scallops in this short-term feeding experiment.

Keywords: Argopecten ventricosus; Gymnodinium catenatum; histopathology; paralyzing shellfish poison; paralysis

\section{Introduction}

The dinoflagellate Gymnodinium catenatum is responsible for red tides in many localities along the Pacific coast of Mexico [1-9]. This planktonic dinoflagellate produces paralyzing shellfish poisons (PSP) that include more than 20 neurotoxic, hydrophilic, tetrahydropurine derivatives [10-12] that make up four subgroups: (1) carbamates (STX, neoSTX, and gonyautoxins (GTX1-GTX4)); (2) $N$-sulfo-carbamoyl (GTX5, GTX6, C1-C4); (3) decarbamoyl (dcSTX, deneoSTX, and dcGTX1-dcGTX4); and (4) deoxydecarbamoyl (doSTX, doneoSTX, and doGTX1) [13]. The action mechanism of PSP in vertebrates is the competitive block of sodium channels in excitable cells that inhibit influx of sodium ions, which in turn produces muscle paralysis or death in the most severe situation $[14,15]$.

Bivalve mollusks are filter feeders that consume toxic dinoflagellates, concentrating and accumulating toxins in their tissues. The shellfish become potentially toxic to other animals $[11,16]$. Incidents of poisoning and death in humans in Mexico (1970-2004) are principally associated with consuming bivalves that ingested Pyrodinium bahamense and G. catenatum [17]. Worldwide, dinoflagellate poisoning is a constant threat to public health and has negative impacts on marine ecology, causing serious economic losses to aquaculture enterprises, fisheries, and tourist industries [18-20]. Many studies over the past several decades have shown that producers of PSP, such as Alexandrium spp. harm bivalves in a number of ways, such as reducing filtering, impairing valve activity, mantle retraction, mucus production, increased melanization of tissues, aggregating of hemocyte, decreased growth [18,21-28], and cause paralysis, as seen in vertebrates [29,30]; these physiological responses vary according to the type of toxic algae and the species of bivalve [31-34].

PSPs undergo chemical and enzymatic transformations that change one molecular form to another, becoming less or more toxic; this takes place in the dinoflagellate cell and the animals that consume the toxins. Although accumulation of PSP in bivalves is closely related to the mass of toxic dinoflagellates, bivalves frequently contain a higher proportion of carbamate toxins (or a lower proportion of $N$-sulfo-carbamoyl toxins) compared to the concentrations in the causative dinoflagellates $[35,36]$. The transformations are mediated principally by reductive cleavage (desulfation and dehydroxylation) and hydrolysis (decarbamoylation and desulfation). Absolute toxicity of PSP frequently varies, with carbamates as the most toxic [37-41]. Toxin levels in bivalves are a function of cell density, duration of exposure, toxicity and relative abundance of the phytoplankton species [11]. Differences in the 
dynamics of uptake of toxins and detoxification mechanisms, localization in organs, and physiological breakdown or transformation determine the persistence of toxins in tissues of bivalves [39-41].

The Pacific calico scallop Argopecten ventricosus is a suspension-feeding bivalve mollusk inhabiting the coast of the Baja California Peninsula of Mexico to the southern coast of Peru. In the Baja California Peninsula, the local commercial fishery for this scallop is of interest to aquaculturists. Ten PSP toxin analogs of several strains of G. catenatum in the Gulf of California and their presence in this scallop from Bahía Concepción $\left(26.75^{\circ} \mathrm{N}, 111.8^{\circ} \mathrm{W}\right)$ have been described; the profile of toxins was similar in the scallops and the dinoflagellate $[8,9]$. In this study, we performed feeding trials under laboratory conditions to determine ingestion, PSP kinetics, paralysis, and histopathology in juvenile A. ventricosus that consumed G. catenatum.

\section{Results and Discussion}

\subsection{Feeding Responses}

The Pacific calico scallop $A$. ventricosus, exposed to toxic dinoflagellate cells, showed immediate behavioral responses after consuming G. catenatum, including partial shell valve closure, production of pseudofeces, and paralysis of the adductor muscle. Scallops fed toxic dinoflagellates have low feeding activity compared to scallops fed non-toxic microalgae (Figure 1). At $2 \mathrm{~h}$, scallops in the control group had completely consumed their food, with peak ingestion at $30 \mathrm{~min}$ after the start of the experiment (Figure 1A). Scallops fed toxic dinoflagellates did not consume all of these cells after $24 \mathrm{~h}$ (Figure 1B). During the 0-2 h time frame, treated scallops filtered moderate quantities of the toxic dinoflagellate with partial shell valve closure; at $4 \mathrm{~h}$, the scallops appeared to filtrate normally. There was a peak at $4 \mathrm{~h}$ associated with the opening of the shell valves, which suggested that normal functioning, with increasing filtration, was re-established. However, at $8 \mathrm{~h}$, the scallops produced pseudofeces and ingestion rates decreased. Scallops can detect chemical and physical differences between particles by pre-ingestive and post-ingestive sorting $[42,43]$. Pseudofeces production has been shown to be a particularly important pre-ingestive mechanism because it not only prevents the animal's ingestive capacity from being exceeded, but also facilitates the process of particle selection, whereby less nutritious particles may be rejected and the quality of the ingested material improved proportionately [44].

PSP is not the only toxin produced by these toxin producers that affect bivalve behavior. Recently, other toxins have been identify in Gymnodinium spp., such as the benzoate saxitoxin analogs [45-49], and gymnodimines [50-53] that could be present in our G. catenatum strain but were not detected with our method. Other PSP producers, such as Alexandrium spp., are also known to produce other toxic compounds, such as ichthyotoxins [54] and allelochemicals [55,56], and it has been reported that A. minutum showed potent toxic effects on brine shrimp Artemia salina [57] and a harpacticoid copepod Euterpina acutifrons [58], independent of PSP effects.

On the other hand, some scallops will preferentially retain larger particles longer than smaller ones, and lighter particles longer than denser ones [59]. The strain of G. catenatum used in our study can form chains of more than 60 organisms, reaching $>1 \mathrm{~mm}$ in length. This could contribute to the avoidance feeding behavior of $A$. ventricosus because general patterns of size selectivity by bivalves 
show positive selection for particles above a lower limit of a few microns, which peaks for mid-sized particles, typically 20-30 $\mu \mathrm{m}$, and particles above these sizes could be rejected [60].

Figure 1. Depletion by juvenile Pacific calico scallops Argopecten ventricosus (shell height $=4.16 \mathrm{~cm} \pm 1.1 \mathrm{~cm}$ ) over $24 \mathrm{~h}$ of $(\mathbf{A})$ Isochrysis galbana control cells and (B) toxic Gymnodinium catenatum cells. G. catenatum cells were given once at a concentration of 3500 cells $\mathrm{mL}^{-1}$ and I. galbana were given once at a concentration of $25 \times 10^{3}$ cells $\mathrm{mL}^{-1}$ in a final volume of $1.5 \mathrm{~L}$. Data are mean $\pm \mathrm{SD}$ (control $n=48$; treated $n=48$ ). Arrows indicate production of pseudofeces.

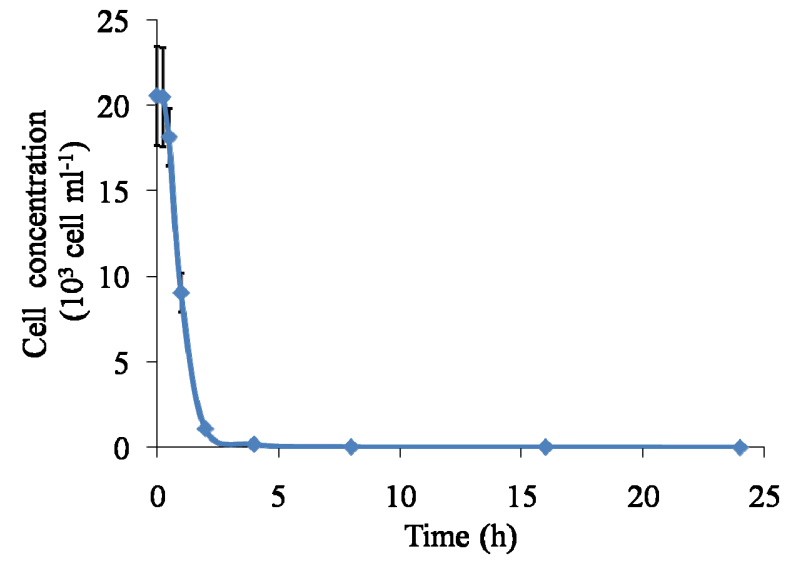

(A)

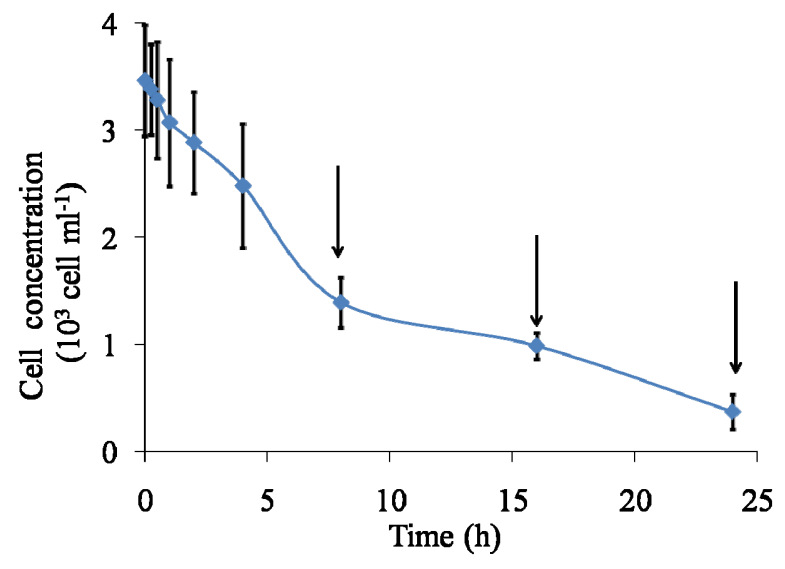

(B)

\subsection{Histopathological Findings}

Representative microphotographs of scallop tissues exposed to G. catenatum are displayed in Figure 2. Gills, adductor muscle, and mantle have more circulating hemocytes in treated scallops compared to the control scallops (Figure 2A-D,G-H). Some dinoflagellates were found in the gills and mantle; occasionally, accumulations of hemocytes aggregated near these dinoflagellates, surrounded with mucus (Figure $2 \mathrm{G}-\mathrm{H}$ ). We also observed epithelial melanization in mantle and gill tissue of scallops fed toxic dinoflagellates (Figure 2E). To test for statistical differences in histological samples, we performed chi-square analysis $\left(\chi^{2}\right.$ test) to identify the relationship between the adverse effects in tissues of scallops by response to the toxic dinoflagellate G. catenatum, expressed in terms of categorical variables indicating the presence or absence of epithelial melanization, mucus production, and hemocyte aggregation (Table 1). Results show a strong association of these histological features in tissues of scallops exposed to G. catenatum cells as food. Epithelial melanization of gills and mantle showed a high positive response to $G$. catenatum $(72.2 \%$ and $86.1 \%$, respectively; $P<0.0001)$. Mucus production and accumulation of hemocytes in gills showed low percentage response to G. catenatum (44.4\% and $30.6 \%$, respectively), however these results were also significantly different compared with controls $(P<0.001)$. In the control group, histological observations of epithelial melanization in mantle and gills were almost negative, with a small percentage of scallops having a positive response ( $16.7 \%$ and $22.2 \%$, respectively). 
Figure 2. Histopathological microphotographs of Argopecten ventricosus, showing effects of exposure to the toxic dinoflagellate Gymnodinium catenatum. Exposed scallops ( $n=12)$ $(\mathbf{B}, \mathbf{D}, \mathbf{F}, \mathbf{G}, \mathbf{H}, \mathbf{I}$, and $\mathbf{J})$ and control scallops $(n=12)(\mathbf{A}, \mathbf{C}$, and $\mathbf{E})$. (B) Hemocyte aggregation in gill filaments; (D) Hemocyte aggregation in adductor muscle; (F) Gills with melanization; (G) Dinoflagellate in gills (arrow); (H) Dinoflagellate in mantle (arrow). Note the hemocyte aggregation (arrow) near the dinoflagellate (asterisk) and mucus production; (I and $\mathbf{J})$ Dinoflagellates in the intestine and in the gonad (arrows).

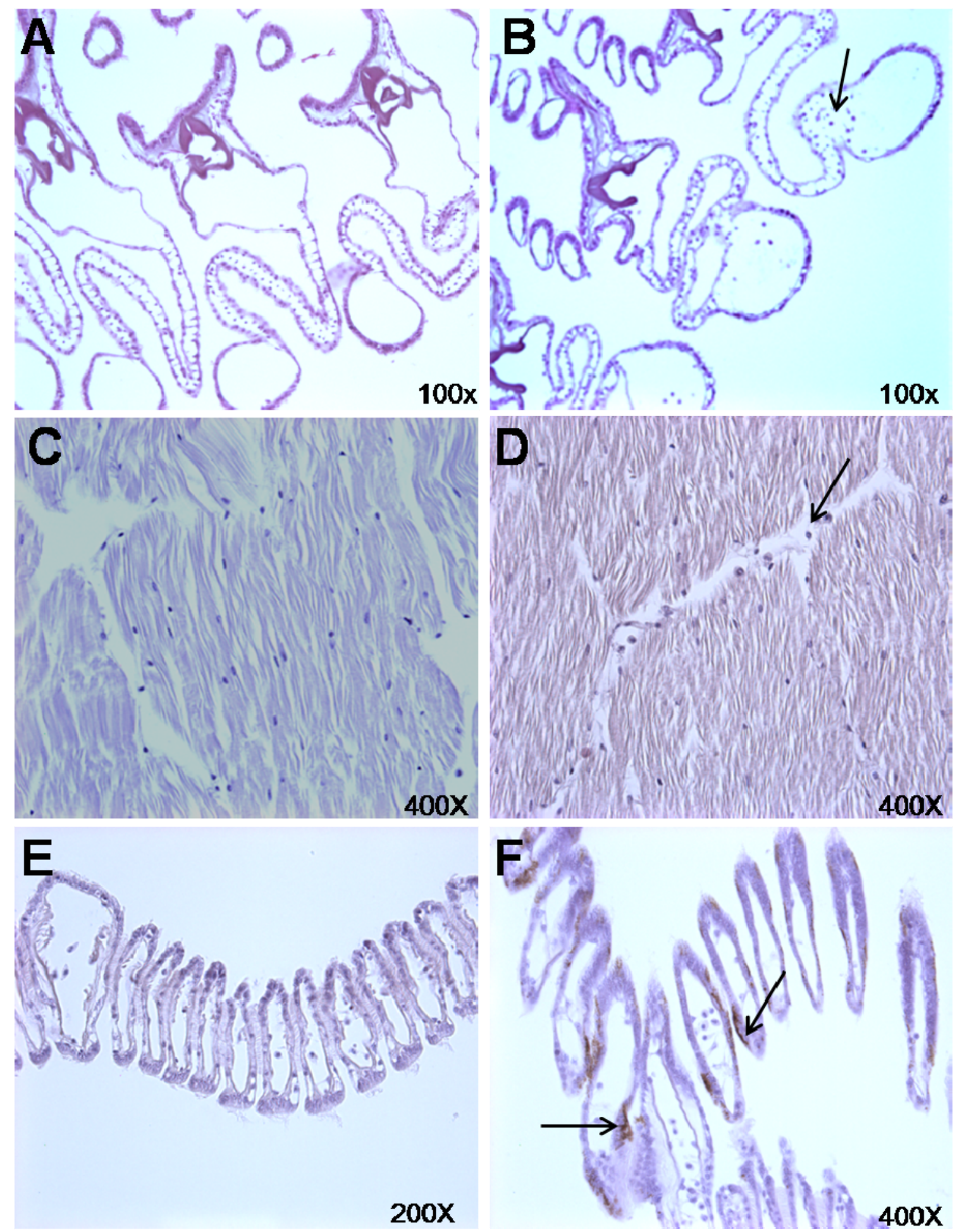


Figure 2. Cont.
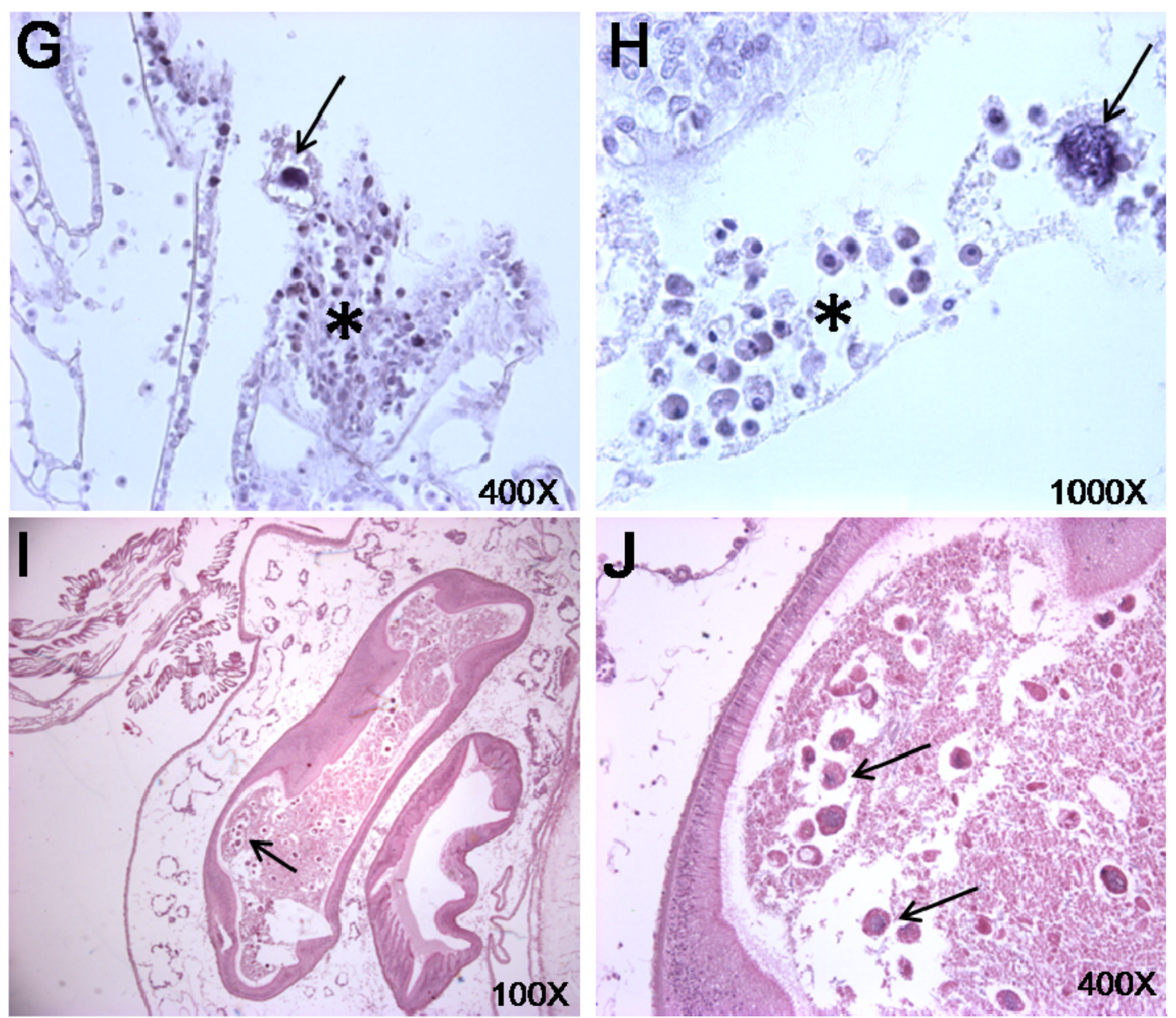

Table 1. Results of contingency table analysis $\left(\chi^{2}\right.$ test) relating epithelial melanization, mucus production, and hemocyte aggregation in a subset of histological sections from Argopecten ventricosus tissues (gills, mantle, and muscle) exposed to Gymnodinium catenatum, compared with scallops that were not exposed to toxic dinoflagellates.

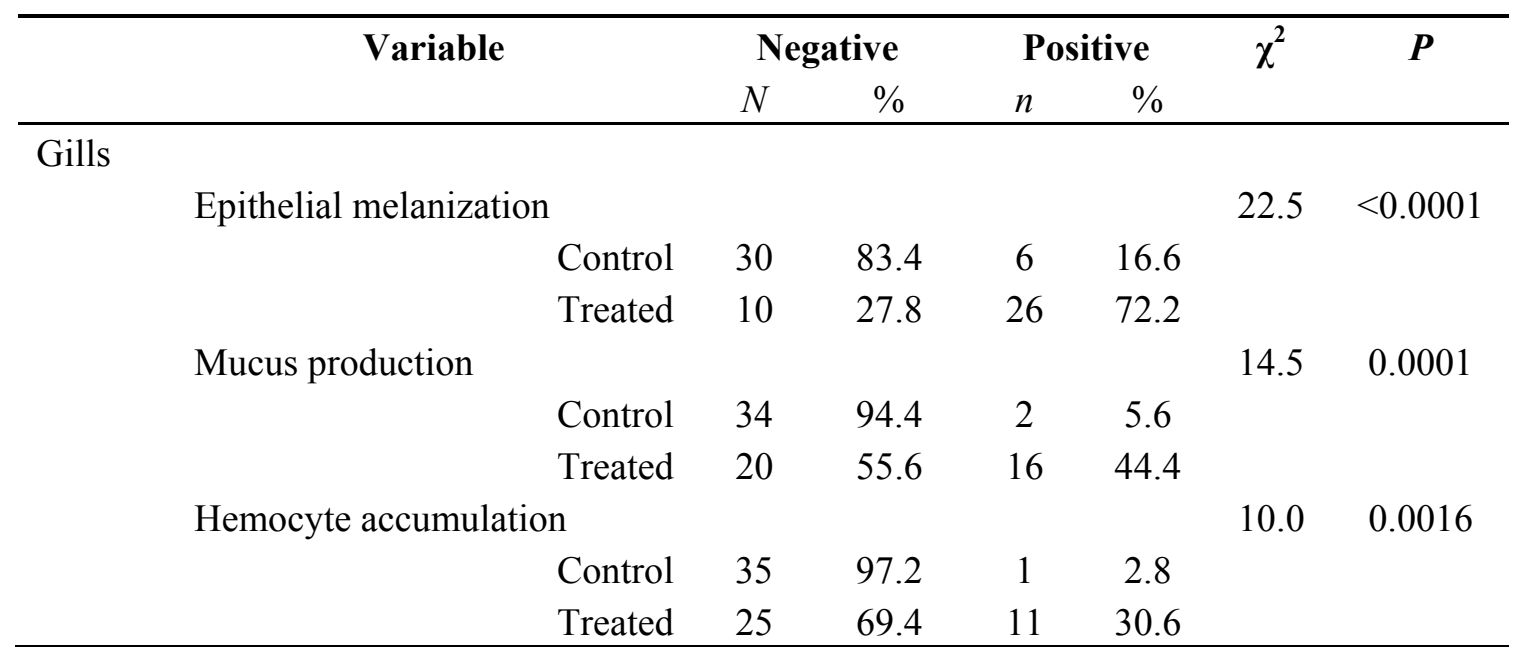


Table 1. Cont.

\begin{tabular}{|c|c|c|c|c|c|c|c|c|}
\hline \multicolumn{9}{|l|}{ Mantle } \\
\hline & \multicolumn{6}{|l|}{ Epithelial melanization } & \multirow[t]{3}{*}{29.6} & \multirow[t]{3}{*}{$<0.0001$} \\
\hline & & Control & 28 & 77.8 & 8 & 22.2 & & \\
\hline & & Treated & 5 & 13.9 & 31 & 86.1 & & \\
\hline & \multirow[t]{3}{*}{ Mucus production } & & & & & & \multirow[t]{3}{*}{22.8} & \multirow[t]{3}{*}{$<0.0001$} \\
\hline & & Control & 31 & 86.1 & 5 & 13.9 & & \\
\hline & & Treated & 11 & 30.6 & 25 & 69.4 & & \\
\hline & \multicolumn{6}{|c|}{ Hemocyte accumulation } & \multirow[t]{3}{*}{22.4} & \multirow[t]{3}{*}{$<0.0001$} \\
\hline & & Control & 35 & 97.2 & 1 & 2.8 & & \\
\hline & & Treated & 17 & 47.2 & 19 & 52.8 & & \\
\hline \multicolumn{9}{|l|}{ Muscle } \\
\hline & \multicolumn{8}{|l|}{ Hemocyte accumulation } \\
\hline & & Control & 33 & 91.7 & 3 & 8.3 & 22.1 & $<0.0001$ \\
\hline & & Treated & 14 & 38.9 & 22 & 61.1 & & \\
\hline
\end{tabular}

$n=$ number of sections observed from 12 treated scallops and 12 controls.

In mollusks and other invertebrates, host defense mechanisms and homeostasis are modulated by circulating hemocytes that ingest and recognize invading microorganisms and engage in phagocytosis, inflammation, and wound repair [61,62]. Accumulation of hemocytes in tissues to attack toxic marine microorganisms has been observed numerous times in bivalves [26,29,30,63]. Mucus is important during ingestion of particles; mucocytes are present in tissue surfaces involved in ingesting and transporting particles and as a first line of defense against pathogens [64-66]. Synthesis of melanin is part of the defense against pathogens; the pigment eliminates pathogens, as well as acting in a chain of defensive reactions involving phenoloxidase [67]. Dinoflagellate cells were also observed in intestinal tissue in all treated scallops (Figure 2I-J). Toxic cells could be ingested, but not digested, and pass through the digestive system intact in feces $[68,69]$. In the juvenile giant lions-paw scallop Nodipecten subnodosus, which naturally occur with Pacific calico scallops, G. catenatum are consumed and lions-paw scallops respond, at high concentrations of these cells, by producing pseudofeces, partially closing their shell valve, reducing feeding rates, increasing melanization, and aggregating hemocytes [26]. Bivalve responses to marine toxic algae are species-specific and depend upon a variety of factors, including the algal species encountered, algal toxicity, algal concentration, cell size and selectivity, history of exposure, season, and differences in digestive function [18,21,22,28,39-41,63,70,71].

\subsection{Paralysis of Scallops}

Scallops were paralyzed at $15 \mathrm{~h}$ when fed 4000 cells $\mathrm{mL}^{-1}$ of $G$. catenatum and recovered hours later. We recorded onset time of paralysis and recovery under two different feeding regimens (Figure 3). When scallops were fed $G$. catenatum for $96 \mathrm{~h}, \sim 60 \%$ of the scallops were paralyzed, only some recovered (Figure 3A) and 10\% died. When scallops were fed G. catenatum for $24 \mathrm{~h}$, followed by non-toxic microalgae, most scallops recovered by 96 h; only a few remained paralyzed (Figure 3B), and none died. The scallops fed non-toxic microalgae (control group) were not paralyzed and are not shown in results. Paralysis of the adductor muscle is well known in oysters [29]. Injecting PSP intramuscularly in Nodipecten subnodosus induces paralysis; these scallops gradually recover in a 
dose-time recovery pattern [30], similar to our observations of shell closure and normal feeding responses, as indicators of recovery.

Figure 3. Juvenile scallops (shell height $=4.03 \mathrm{~cm} \pm 0.4 \mathrm{~cm}$ ): (A) fed 4000 cells $\mathrm{mL}^{-1}$ Gymnodinium catenatum for $96 \mathrm{~h}$, and (B) fed 4000 cells $\mathrm{mL}^{-1} G$. catenatum cells for $24 \mathrm{~h}$ and afterward fed $10 \times 10^{3}$ cell $\mathrm{mL}^{-1}$ non-toxic microalgae Isochrysis galbana. Paralysis and recovery time were recorded for each individual. In both treatments, data were obtained at $3,6,12,24,3648,60,72,84$, and $96 \mathrm{~h}$. Control scallops were fed $25 \times 10^{3}$ cell $\mathrm{mL}^{-1}$ non-toxic microalgae I. galbana, also for $96 \mathrm{~h}$, and no paralysis was observed. Data represent mean $\pm \mathrm{SD}(\operatorname{control} n=20$; treated $n=30)$.

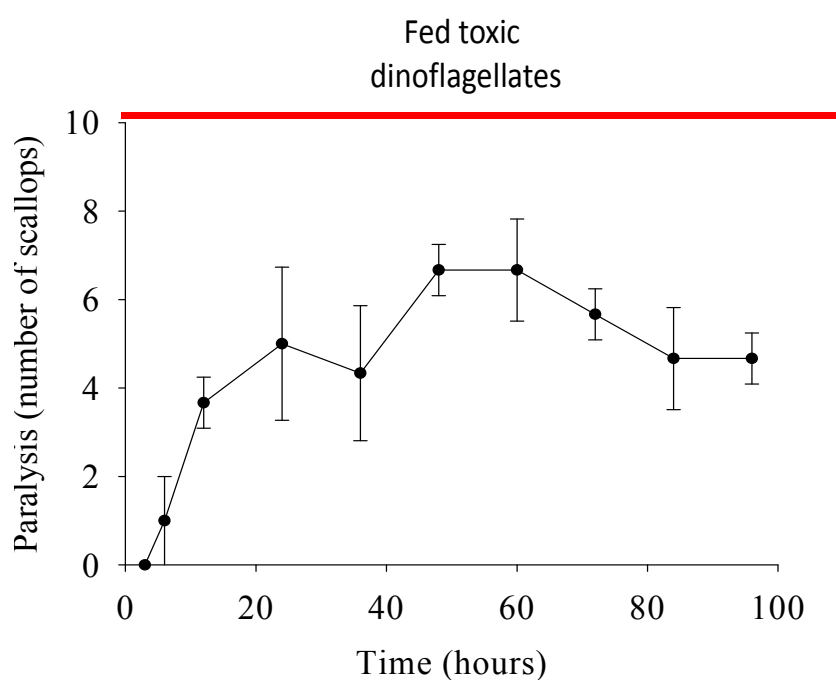

(A)

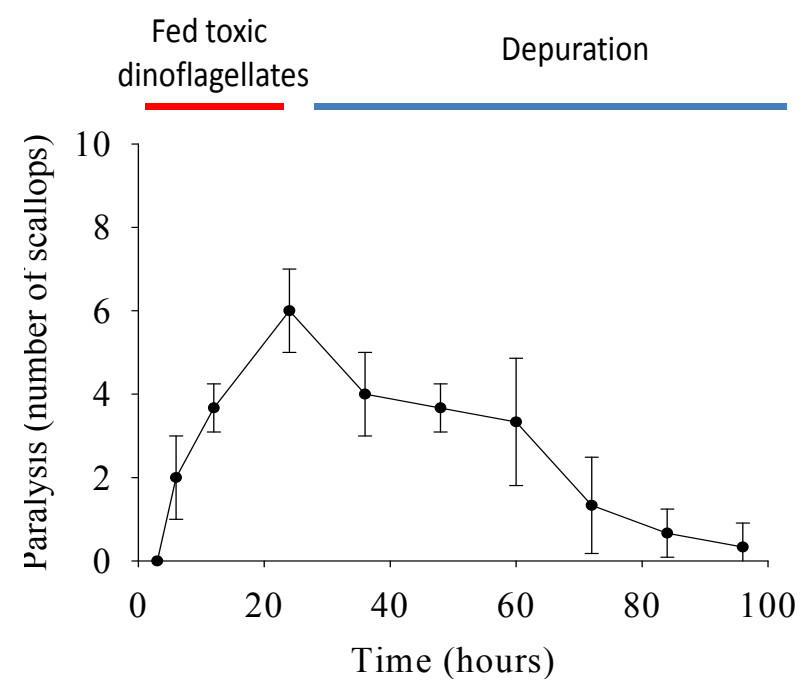

(B)

Hemocytes increased when scallops were fed high concentrations of toxic dinoflagellates (4000 cells $\mathrm{mL}^{-1}$; Figure 4), which was markedly different from the control group. About $25 \%$ of treated scallops became paralyzed; below this concentration, scallops were not significantly different from the control group. Although we did not use a long-period feeding treatment, toxic dinoflagellates could produce immunosuppression in the scallops, as was the case in $N$. subnodosus when toxins were injected into the adductor muscle (100 mouse units; MU), permanent paralysis occurs and hemocytes in hemolymph decreased [30]. However when these scallops were fed toxic dinoflagellates, they were not paralyzed $[25,26]$. When several species of bivalves received PSP by intramuscular injection, the minimum lethal dose was remarkably high, $300 \mathrm{MU} 20 \mathrm{~g}^{-1}$, compared to the sensitivity of fish at 0.5-33 MU $20 \mathrm{~g}^{-1}$ and crustaceans at 0.5-10 MU $20 \mathrm{~g}^{-1}[72,73]$.

Other effects produced by PSP in bivalves are the absence of response to mechanical stimulation of the gills and adductor muscle in gaping Crassostrea virginica [29], incapacity to burrow, associated with muscle paralysis, in the soft-shell clam Mya arenaria [74], paralysis in adductor muscle after spawning events in mussels [69] and important morphological alterations of the adductor muscle in C. gigas [75]. Although scallops in our work become paralyzed, scallops do not die and this resistance in some bivalve species is related to differences in toxin accumulation, where resistant species, such as Mytilus edulis, accumulate toxins in tissues at greater rates than sensitive bivalves [11,76]. Reduction in nerve sensitivity in clams is the result of natural mutations of amino acid residues that decreases the 
affinity of the saxitoxin-binding site in the sodium channel pore [77], which may explain why there are PSP-resistant and non-resistant bivalve species. Highly-sensitive species, such as the hard clam Mercenaria mercenaria and the bay scallop A. irradians, exhibit physiological and behavioral mechanisms to avoid toxicity by reducing filtration rate and rapid shell clapping to clear the gills of toxic cells [21].

Figure 4. Hemocyte counts over $48 \mathrm{~h}$ in juvenile Pacific calico scallops Argopecten ventricosus (shell height $=4.98 \mathrm{~cm} \pm 0.7 \mathrm{~cm}$ ) fed different concentrations of Gymnodinium catenatum under controlled conditions. Hemolymph was withdrawn and counted at 6, 12, 24 , and $48 \mathrm{~h}$. At the highest concentration of toxic alga cells, some scallops were paralyzed. Paralyzed and non-paralyzed scallops were tested. Data represent mean \pm SD (control $n=10$; treated $n=10$ ). Asterisk indicates statistically significant differences between the control and treated groups $(P<0.05)$.

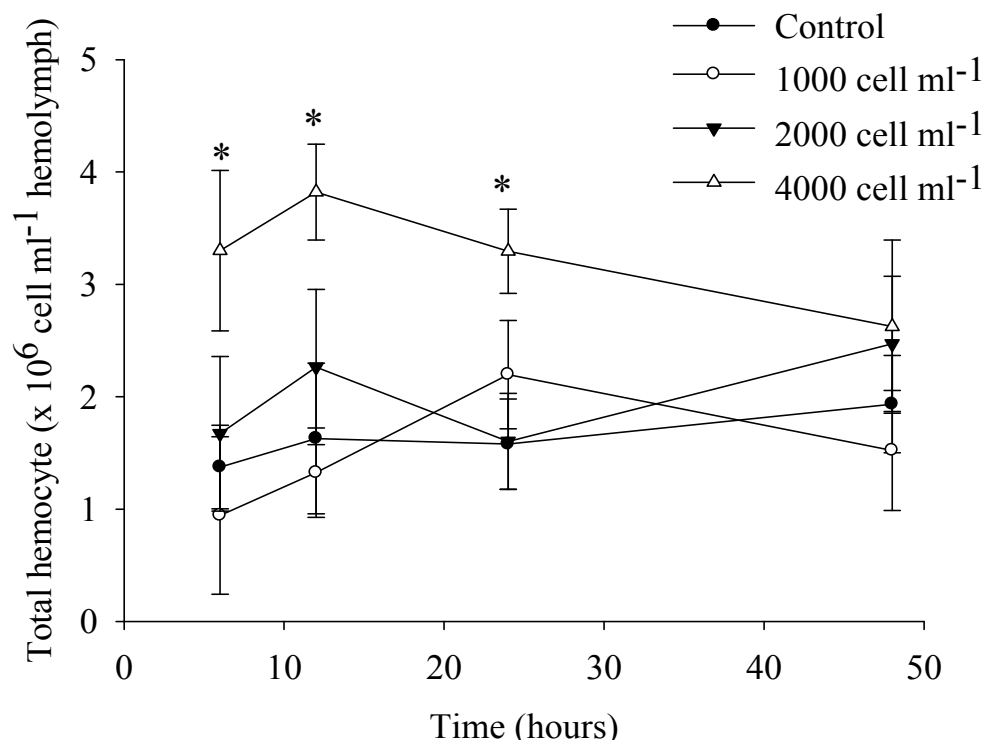

\subsection{Analysis of Toxins}

Composition of PSP derivatives in G. catenatum cells, before chemical hydrolysis, was limited to $N$-sulfo-carbamoyl toxins ( $\mathrm{C} 1$ and $\mathrm{C} 2$ ). The toxin profiles of dinoflagellates isolated from various areas have been elucidated by many research groups. These studies indicate that the toxin profile is often specific to a species of dinoflagellate. According to Oshima et al. [35] G. catenatum shows a characteristic toxin profile which consists of $N$-sulfo-carbamoyl toxins such as $\mathrm{B}$ and $\mathrm{C}$ toxins as major components.

The toxin content of different tissues we found in $A$. ventricosus also showed that the principal PSP native components were $\mathrm{C} 1$ and $\mathrm{C} 2$ toxins. It is common that bivalve tissues transform $\mathrm{N}$-sulfo-carbamoyl from toxic dinoflagellates to more toxic carbamates toxins. Various C-toxins undergo chemical and enzyme-mediated reductive cleavage (desulfuration and dehydroxylation) and hydrolysis (decarbamoylation and desulfuration) in vivo [78-81]; biotransformations sometimes cause increased toxicity, compared to intact toxins transmitted by dinoflagellates [80]. Only $\mathrm{C} 1$ and $\mathrm{C} 2$ toxins were present in G. catenatum and A. ventricosus tissues in our short-term feeding trial, which indicated a low capacity 
of transformation to carbamate toxins in vivo, similar to results observed in samples from the field by Band-Schmidt et al. [8] with the same species. Band-Schmidt et al. [8] principally found ten toxins in $G$. catenatum cells and samples of $A$. ventricosus, but only dcSTX, dcGTX2, dcGTX3, C1, and C2 were always present in all strains of $G$. catenatum at both growth stages and in the profiles in A. ventricosus. Although Band-Schmidt et al. [8] used the same protocol for toxin extraction, and the toxic dinoflagellates come from similar areas, we did not detect decarbamoyl toxins. The total toxin content in G. catenatum in our study was similar to described PSP profiles of 16 isolated and cultured strains of $G$. catenatum from the Gulf of California, where the average toxicity of $G$. catenatum strains was $26 \pm 6$ after 17 days of growth and $28 \pm 18$ pg STXeq cell $^{-1}$ after 22 days of growth. Differences in toxin profiles in bivalves and in dinoflagellates might be explained by cell culture conditions, specific uptake, elimination, and enzymatic and chemical transformations of accumulation in tissues, and in the methods used [82-89].

To analyze whether $N$-sulfo-carbamoyl toxins could convert to carbamate toxins, we examined the possibility of transformation of these PSP analogs performing a chemical hydrolysis with $1 \mathrm{M} \mathrm{HCl}$; it also serves to make comparisons of toxin concentration with the analytical data obtained with other works that use direct hydrolysis to report their results. Different extraction conditions may lead to differences in toxin profiles and to different results when these analytical data are expressed as STX equivalents. After chemically-induced hydrolysis, we detected carbamate toxins and epimers GTX2/3 in $G$. catenatum cells and A. ventricosus tissues. PSP are prone to various conversions, depending on the $\mathrm{pH}$; when heated at low $\mathrm{pH}$, toxins with the $\mathrm{N}$-sulfo-carbamoyl moiety as a side chain are partially converted to the corresponding carbamate toxins through hydrolysis [13]. These conversions take place when PSP are boiled with strong acid and result in a change of PSP analogues with a low toxicity, such as $\mathrm{C} 1$ and $\mathrm{C} 2$, into ones with a higher toxicity, such as GTX2 and GTX3. Conversion does not take place in weak acids, such as acetic acid solutions, $\sim$ pH 3-4. Because the Cs toxins we analyzed could be converted to their respective carbamate analogs, in long-term trials, in vivo biotransformations may occur in A. ventricosus.

Table 2 shows accumulation of PSP in different tissues of $A$. ventricosus. No toxins were detected in tissues of the control group, and we did not measure other toxins that could be present in G. catenatum. In A. ventricosus before hydrolysis, the mantle had the highest concentration of toxins, followed by the digestive gland-stomach complex, gills, and finally by the muscle, kidney, and rectum group. Generally, the tissues that accumulated the most PSP are in contact with food particles when they are ingested and during digestion. Commonly, the digestive gland is the tissue that accumulates most of the toxin body burden, similar to other scallops, such as Placopecten magellanicus, Patinopecten yessoensis, and Nodipecten subnodosus [25,83-85]. Since the digestive gland carries out digestive processes and transformation of toxins, the digestive gland-stomach complex is probably the most important tissue in toxin metabolic processes [29,35]. Thus, accumulation of PSP depends on the capacity for biotransformation and selectivity among tissues and variations among individuals $[10,89,90]$. 
Table 2. Accumulation of PSP in different tissues of Argopecten ventricosus (pg STX eq g ${ }^{-1}$ wet weight) and in Gymnodinium catenatum cells (pg STX eq cell ${ }^{-1}$ ).

\begin{tabular}{lcc}
\hline Extract & C1 & C2 \\
\hline Gymnodinium catenatum & $45 \pm 6$ & $15 \pm 6$ \\
Tissue controls & ND & ND \\
Digestive gland-stomach & $38 \pm 3$ & $189 \pm 13$ \\
Mantle & $41 \pm 8$ & $202 \pm 37$ \\
Gills & $10 \pm 1$ & $51 \pm 6$ \\
Muscle, kidney, rectum & $11 \pm 2$ & $56 \pm 8$ \\
\hline
\end{tabular}

Data from tissues represent mean $\pm \mathrm{SD}$ (control $n=12$; treated $n=12)$. $\mathrm{ND}=$ Not detected.

Band-Schmidt et al. [91] reviewed PSP events from G. catenatum in the Pacific areas of Mexico. Low toxicities $\left(<1000,>50 \mu \mathrm{g}\right.$ STXeq $\left.100 \mathrm{~g}^{-1}\right)$ were detected in $A$. ventricosus [92,93], compared with high toxicities ( $>1000 \mu \mathrm{g}$ STXeq $100 \mathrm{~g}^{-1}$ ) found in oysters and mussels [94-97]. Some authors claim that accumulation profiles of PSP toxins in bivalves differ significantly among bivalve species [97-99]. For example, during toxic algal blooms, the scallops P. yessoensis and Chlamys nipponensis become much more toxic than mussels under the same environmental conditions, and their depuration requires several months. Mussels and oysters usually accumulate high levels of toxicity rapidly and also decline rapidly once the causative dinoflagellates disappear. Thus, the season of sampling, concentrations of algal cells, and physicochemical parameters are important factors in determining dinoflagellate and bivalve toxicity [91].

\section{Experimental Section}

\subsection{Algal Culture and Source of Scallops}

Gymnodinium catenatum strain GCQM-2 was obtained from the Marine Dinoflagellate Collection (CODIMAR) at CIBNOR in La Paz, Mexico [100]. The cells were cultured in GSe medium [101] prepared with filtered $(0.7 \mu \mathrm{m})$ seawater in $20 \mathrm{~L}$ glass flasks on a $16 \mathrm{~h}$ light: $8 \mathrm{~h}$ dark photocycle at $21^{\circ} \mathrm{C}$ under $70 \mathrm{~W}$ fluorescent lamps and anaerobic conditions.

Cultivated juvenile scallops (shell height $=4.2 \pm 1.1 \mathrm{~cm}$ ) were collected from farms at Rancho Bueno, Baja California Sur, Mexico $\left(24^{\circ} 32^{\prime} \mathrm{N}, 111^{\circ} 42^{\prime} \mathrm{W}\right)$ and transported to CIBNOR. Groups of 12 were placed in a $40 \mathrm{~L}$ plastic tank containing $1 \mu \mathrm{m}$ filtered seawater. The water was maintained at $22{ }^{\circ} \mathrm{C}$, with salinity at 35 practical salinity units (psu), and constantly aerated with air stones. Filtered seawater was completely replaced every two days. During acclimation (14-21 days), the scallops were fed a mix of microalgae (Chaetoceros calcitrans, Chaetoceros gracilis, and I. galbana; 1:1:1 ratio, $200 \times 10^{3}$ cells $\mathrm{mL}^{-1}$ of each), obtained from the Microalgae Laboratory at CIBNOR. C. calcitrans and C. gracilis were cultured in $20 \mathrm{~L}$ plastic bags in $\mathrm{F} / 2$ growth medium at $22{ }^{\circ} \mathrm{C}$ with constant illumination at salinity of $32 \mathrm{psu}$. I. galbana strain ISG-1 was grown in MA-F/2 medium at $22{ }^{\circ} \mathrm{C}$ at $32 \mathrm{psu}$ in $20 \mathrm{~L}$ plastic bags under constant illumination. I. galbana was also used as the non-toxic diet for the control group. G. catenatum cultures were harvested during the late exponential growth phase; the three microalgae were harvested during the stationary growth phase. To estimate concentrations at harvest, cells were counted in Sedgewick-Rafter counting chambers under an optical microscope 
$(400 \times)$ for the dinoflagellates and an electronic particle counter (Coulter Multi-sizer) for the other microalgae.

\subsection{Feeding Experiments}

Three feeding experiments were performed: (1) A $24 \mathrm{~h}$ trial at one concentration of G. catenatum to study depletion of $G$. catenatum, accumulation and biotransformation of PSP, and observe histological changes; (2) A $48 \mathrm{~h}$ feeding experiment with different concentrations of $G$. catenatum to analyze number of hemocytes in A. ventricosus; and (3) A $48 \mathrm{~h}$ feeding experiment at a high concentration of G. catenatum to measure paralysis and recovery time of scallops. For filtration of G. catenatum and accumulation and biotransformation of PSP, 36 scallops were used; for histopathology, 12 scallops; for total hemocytes count, 80 scallops; and for paralysis studies, 100 scallops. Before the trials, specimens were placed in $1 \mu \mathrm{m}$ filtered seawater without food for $24 \mathrm{~h}$ to clear their digestive tract.

\subsubsection{Experiment 1}

To assay accumulation and biotransformation of PSP, 48 juvenile scallops (shell height $=4.2 \pm 1.1 \mathrm{~cm}$ ) were used and 24 scallops for histopathology study. Groups of six scallops were placed in six $1.5 \mathrm{~L}$ plastic containers. Each group was fed 3500 cells $\mathrm{mL}^{-1}$ G. catenatum in a volume of $1.5 \mathrm{~L}$ filtered seawater at the beginning of the trial under closed, controlled conditions $\left(22{ }^{\circ} \mathrm{C}, 35 \mathrm{psu}\right)$, and responses were observed for $24 \mathrm{~h}$. Another six $1.5 \mathrm{~L}$ plastic containers, each with six scallops, were used as the control group and fed I. galbana $\left(25 \times 10^{3}\right.$ cells $\left.\mathrm{mL}^{-1}\right)$. To reduce cell growth during the experiment, algae were maintained in the dark and kept in suspension with a bubbling air stone.

\subsubsection{Experiment 2}

Groups of five juvenile scallops were placed in $1.5 \mathrm{~L}$ plastic containers, four containers for each concentration of G. catenatum. Four additional containers were used for the control group, which were fed I. galbana $\left(25 \times 10^{3}\right.$ cells $\left.\mathrm{mL}^{-1}\right)$ at the beginning of the experiment. Scallops (shell height $=5 \pm 0.7 \mathrm{~cm}$ ) were fed one of three concentrations $\left(1000,2000\right.$, or 4000 cells $\left.\mathrm{mL}^{-1}\right)$ of $G$. catenatum in a volume of $1.5 \mathrm{~L}$ filtered seawater at the beginning of the trial; the water was completely changed at $24 \mathrm{~h}$; the same concentrations of $G$. catenatum was added for the next $24 \mathrm{~h}$ of the trial $\left(22{ }^{\circ} \mathrm{C}, 35 \mathrm{psu}\right)$. Five scallops from one control container and 5 scallops from one treated container were used at 6, 12, 24, and $48 \mathrm{~h}$ for hemolymph extraction. Hemolymph was withdrawn and hemocytes counted (see below). Hemocyte counts were recorded for each individual and no scallop was withdrawn more than once. At the highest concentration of toxic alga cells, some scallops were paralyzed; paralyzed and non-paralyzed scallops were tested.

\subsubsection{Experiment 3}

Juvenile scallops (shell height $=4 \pm 0.4 \mathrm{~cm}$ ) were fed 4000 cells $\mathrm{mL}^{-1}$ G. catenatum in a volume of $1.5 \mathrm{~L}$ filtered seawater under closed, controlled conditions $\left(22{ }^{\circ} \mathrm{C}, 35 \mathrm{psu}\right)$. The seawater was completely changed every $24 \mathrm{~h}$ for three days. The same concentration of G. catenatum was added each day to the replacement seawater. Ten scallops were placed in $1.5 \mathrm{~L}$ plastic containers. Three 
containers were used in this trial; two other containers with 10 scallops each were fed the non-toxic microalga I. galbana $\left(25 \times 10^{3}\right.$ cells $\left.\mathrm{mL}^{-1}\right)$. The onset of paralysis and recovery time of treated scallops was observed and recorded for 96 h. A similar trial was carried out in parallel, but G. catenatum was added only at the beginning of the experiment, and at $24 \mathrm{~h}$; the scallops were fed the non-toxic microalgae I. galbana at a lower concentration $\left(10 \times 10^{3}\right.$ cell $\left.\mathrm{mL}^{-1}\right)$ to record onset of paralysis and recovery time over the following $72 \mathrm{~h}$. Previously, we observed that, when scallops are paralyzed, they continue to feed at a reduced level of activity. This is the basis for feeding them a low concentration of non-toxic microalgae. In both cases, data were recorded at 3, 6, 12, 24, 36, 48, 60, 72, 84, and $96 \mathrm{~h}$.

\subsection{Depletion of Algal Cells}

Depletion of algal cells in Experiment 1 was measured in the closed systems. Samples of the suspension $(1 \mathrm{~mL})$ from each container, fixed in Lugol's solution (1:1, v:v), were counted under an optical microscope or in the electronic particle counter at the beginning of exposure $(0 \mathrm{~h})$ and at 0.25 , $0.5,1,2,4,8,16$, and $24 \mathrm{~h}$ after exposure. Scallops of eight containers (control $n=24$; treated $n=24$ ) were sacrificed at $24 \mathrm{~h}$ to determine total wet tissue weight, shell size and toxin content.

\subsection{Histopathological Examination}

Scallops from another four containers from Experiment 1 were processed for histopathology examination (control $n=12$; treated $n=12$ ). Whole animals were removed from their shells and preserved in Davidson's solution. Samples of tissues were embedded in paraffin, sectioned to $5 \mu \mathrm{m}$, and stained in hematoxylin-eosin. Permanent slides were examined under an optical microscope and recorded with digital micrographs.

Contingency Tables

To understand the relationship between histological type and response to PSP, we made contingency tables with the following characteristics: (1) Histological type: epithelial melanization, mucus production, hemocyte accumulation; (2) Response: positive and negative; and (3) Frequency: number of organisms in a given histological type and response category. With these data, we used the chi-square test ( $\chi^{2}$ test) with statistical software (JMP 7, SAS Institute, Cary, NC, USA). Data come from three random histological sections of each scallop, which included gills, mantle, and adductor muscle cut longitudinally from the middle of the adductor muscle with a difference of approximately 50-80 $\mu \mathrm{m}$ between sections. For each histological section, the percentage of the responses was tabulated as the coverage area of the effect (presence of brown pigment melanin and occurrence of mucus) or as accumulation of hemocytes (frequency of number of aggregations). The area occupied by melanin and mucus in epithelia was determined with an image analyzer (Image Pro Plus v4, Media Cybernetics, Bethesda, MD, USA) at $40 \times\left(7.9 \mathrm{~mm}^{2}\right)$ from three different slices from each specimen, similar to the method described by Rodríguez-Jaramillo et al. [102]. Ten images were taken randomly in each tissue from each section and image analyses were based on the intensity of the tissue-specific color (melanin) and the area that was manually selected (mucus), which were automatically calculated 
in pixels and expressed in $\mu \mathrm{m}^{2}$. The reported response coverage area for each effect was calculated as: $\mathrm{RCA}=($ occupation area affected/total area $) \times 100$. A positive response was indicated when the RCA covered $>50 \%$ (from a mean of the ten images); a negative response was indicated when the RCA was $<50 \%$. Accumulation of hemocytes was positive when 5 or more aggregations were observed.

\subsection{Paralysis Studies}

\subsubsection{Determination of Paralysis}

In feeding experiments, some scallops were paralyzed and recovered hours later. In Experiment 3, kinetics of paralysis was assessed, as described by Hégaret et al. [29] after appearance of a gaping shell. Gaping scallops were mechanically stimulated on the gills and adductor muscle with a micropipette; if the scallops did not react with movement, they were considered paralyzed. Viability of paralyzed scallops was determined by examining the clarity of the water and production of feces after feeding low concentrations of non-toxic microalgae. Recovery of paralyzed scallops was determined by observation of reduced shell gaping and recovery of muscle function.

\subsubsection{Hemocytes Count at Different Toxic Cells Concentrations}

To extract hemolymph in Experiment 2, each scallop's valves were pried open and kept separated with a knife blade; the hemolymph was withdrawn from the adductor muscle with a 26 gauge needle attached to a $1 \mathrm{~mL}$ syringe. Approximately $0.5-1.0 \mathrm{~mL}$ hemolymph per scallop was drawn and immediately put on ice to avoid clumping. Total hemocyte count was recorded with an electronic particle counter (Coulter Multi-sizer). This experiment was done twice and data from both trials were analyzed together by the Student's $t$-test with SPSS 16 software (eight containers per concentration at each time, see section 3.2.2). Significance was set at $P<0.05$.

\subsection{Analysis of Toxins}

\subsubsection{Algal and Scallop Toxins}

Two liters of $G$. catenatum culture were harvested for analysis by extracting the biomass by centrifugation at $500 \times \mathrm{g}$. The precipitate was suspended in $50 \mathrm{~mL} 0.05 \mathrm{M}$ acetic acid and then homogenized with glass beads ( $5 \mathrm{~mm}$ dia.). Three successive washes by stirring were done ( $30 \mathrm{~s}$ vortex: $30 \mathrm{~s}$ ice). The supernatants were pooled. Examination under an optical microscope of the remaining cell debris after homogenization revealed that the cells had been completely disrupted. Toxins were stored at $-80{ }^{\circ} \mathrm{C}$.

To study the accumulation and biotransformation of toxins, the scallops from three of the containers from Experiment 1 were used at the end of the one-day exposure. All scallops in each container were weighed, pooled, and stored at $-80{ }^{\circ} \mathrm{C}$. About 5-10 g of tissue was emulsified in $0.05 \mathrm{M}$ acetic acid in proportions of 1:2 (tissue weight:acid volume) in a homogenizer (Polytron, Kinematica, Bohemia, NY, USA). The suspension was centrifuged for $10 \mathrm{~min}$ at $5000 \times \mathrm{g}$, and the supernatant was filtered with a single-use syringe-filter $(0.2 \mu \mathrm{m})$. The extracts (cells and tissues) containing PSP were combined with $150 \mathrm{~mL} 0.03 \mathrm{~N}$ acetic acid and $37 \mu \mathrm{L} 1 \mathrm{M} \mathrm{HCl}$ and mixed in a vortex for $30 \mathrm{~s}$ and then hydrolyzed by 
heating for $15 \mathrm{~min}$ at $90{ }^{\circ} \mathrm{C}$. The mixture was neutralized with $75 \mu \mathrm{L}$ (1 M sodium acetate) and stirred for $30 \mathrm{~s}$. Samples were cooled to room temperature.

\subsubsection{HPLC Analysis}

PSP were measured under the conditions described previously, using post-column derivatization HPLC with the fluorescent online detection method [78,79]. Briefly, a $20 \mu \mathrm{L}$ pretreated sample was injected into a reverse phase column C18 (4.6 mm ID, $5 \mu \mathrm{m}$ particle size, $25 \mathrm{~cm}$ long, and $200 \AA$ pore size) with a mobile phase composed of a solution of $11 \mathrm{mM}$ octanesulfonic acid and $40 \mathrm{mM}$ phosphoric acid with $\mathrm{pH}$ adjusted to 6.9 with ammonia phosphate in $15 \%$ tetrahydrofurane. Column eluted fractions were mixed with $10 \mathrm{mM}$ periodic acid in $550 \mathrm{mM}$ buffered ammonia at $\mathrm{pH} 9.0$ at $0.3 \mathrm{~mL} \mathrm{~min}{ }^{-1}$, heated to $50{ }^{\circ} \mathrm{C}$ by passing through a coil of Teflon tubing $(0.2 \mathrm{~mm} \mathrm{ID,} 10 \mathrm{~cm}$ long), and then mixed with $1 \mathrm{M}$ nitric acid at a flow rate of $0.4 \mathrm{~mL} \mathrm{~min}^{-1}$ just before entering the monitor. The fluoromonitor was set to excite at $330 \mathrm{~nm}$ and emit at $395 \mathrm{~nm}$. Detection limits for the method are 247, 17, 77, 16, and $7 \mathrm{pg} \mathrm{mL}^{-1}$ for GTX1, $4 \mathrm{pg} \mathrm{mL}^{-1}$ for GTX2, and $3 \mathrm{pg} \mathrm{mL}^{-1} \mathrm{NeoSTX}$, dcSTX, and STX. PSP were identified by comparing chromatograms obtained from samples with standard solutions of STX, NeoSTX, GTX1, GTX2, GTX3, GTX4, and dcSTX (National Research Council Canada, Institute for Marine Biosciences, Certified Reference Materials Program, Halifax, NS). Quantification of PSP content used the factor response (peak area/toxin concentration) obtained with the injection of known quantities of toxin standards. Toxicity in tissues is expressed as picograms of saxitoxin equivalents $\mathrm{g}^{-1}$ scallop meat (pg STXeq $\mathrm{g}^{-1}$ ), that is, the relative toxicity of each derivative with respect to potential poison, namely saxitoxin (STX). Toxicity in cell is expressed in pg STXeq cell ${ }^{-1}$.

\section{Conclusions}

Similar physiological reactions occur in Argopecten ventricosus, as in other scallops, when ingesting the toxic dinoflagellate Gymnodinium catenatum, including reduced filtering, melanization of epithelial cells, and aggregation of hemocytes; however, paralysis of the adductor muscle generally had not been regarded as important in other scallops feeding on dinoflagellates that produce PSP. After initial consumption of toxic dinoflagellates, high concentrations of $N$-sulfo-carbamoyl toxins (epimers $\mathrm{C} 1$ and $\mathrm{C} 2$ ) occurred in the mantle and digestive gland-stomach complex and, to a lesser extent, in the gills and the adductor muscle-kidney-rectum group. We only found epimers of $\mathrm{C} 1$ and $\mathrm{C} 2$ in the short-term trial, suggesting that biotransformation in different tissues of this scallop is not obvious, as in other bivalves.

\section{Acknowledgments}

We thank S.J. Delgado Del Villar for analyzing toxins and use of the Laboratory of Marine Biotoxins of UNAM. Editorial services were provided by Ira Fogel of CIBNOR. Financial support was partly provided by Centro de Investigaciones Biologicas del Noroeste (CIBNOR grant AC 3.1), N.E. was supported by a fellowship from Consejo Nacional de Ciencia y Tecnologia of Mexico (172583). 


\section{References}

1. Graham, H.W. Gymnodinium catenatum, a new dinoflagellate from the Gulf of California. Trans. Am. Microsc. Soc. 1943, 62, 259-261.

2. Mee, L.D.; Espinoza, M.; Díaz, G. Paralytic shellfish poisoning with a Gymnodinium catenatum red tide of the Pacific Coast of Mexico. Mar. Environ. Res. 1986, 19, 77-92.

3. Cortés, A.R.; Manrique, F.A.; Luna-Soria, R. Occurrence of red tides in the eastern coast of the Gulf of California. Rev. Lat. Microbiol. 1995, 37, 337-342.

4. Ochoa, J.L.; Sánchez-Paz, A.; Cruz-Villacorta, A.; Núñez-Vázquez, E.; Sierra-Beltrán, A. Toxic events in the northwest Pacific coastline of Mexico during 1992-1995: Origin and impact. Hydrobiologia 1997, 352, 195-200.

5. Ochoa, J.L.; Sierra-Beltrán, A.; Alonso-Colmenares, G.; Barradas-Sánchez, H.; Cruz-Villacorta, A.; Nuñez-Vázquez, E.; Sánchez-Paz, A. Biotoxins in the Pacific coast of Mexico. In Mycotoxins and Phycotoxins: Developments in Chemistry, Toxicology, and Food Safety, Proceedings of IX IUPAC (International Union Purity Analytical Chemistry) International Symposium on Mycotoxins and Phycotoxins, Rome, Italy, 27-31 May 1996; Miraglia, M., van Egmond, H.P., Brera, C., Gilbert, J., Eds.; Alaken: Fort Collins, CO, USA, 1998; pp. 441-448.

6. Alonso-Rodríguez, R.; Ochoa, J.L. Hydrology of winter-spring “red tides" in Bahía de Mazatlán, Sinaloa, México. Harmful Algae 2004, 3, 163-171.

7. Gárate-Lizárraga, I.; Bustillos-Guzmán, J.J.; Morquecho, L.; Band-Schmidt, C.J.; Alonso-Rodríguez, R.; Erler, K.; Luckas, B.; Reyes-Salinas, A.; Góngora-González, D.T. Comparative paralytic shellfish toxin profiles in the strains of Gymnodinium catenatum Graham from the Gulf of California, Mexico. Mar. Pollut. Bull. 2005, 50, 208-236.

8. Band-Schmidt, C.J.; Bustillos-Guzmán, J.; Gárate-Lizárraga, I.; Lechuga-Devèze, C.H.; Reinhardt K.; Luckas, B. Paralytic shellfish toxin profile in strains of the dinoflagellate Gymnodinium catenatum Graham and the scallop Argopecten ventricosus G. B. Sowerby II from Bahía Conception, Gulf of California, Mexico. Harmful Algae 2005, 4, 21-31.

9. Band-Schmidt, C.; Bustillos-Guzmán, J.; Morquecho, L.; Gárate-Lizárraga, I.; Alonso-Rodríguez, R.; Reyes-Salinas, A.; Erler, K.; Luckas, B. Variations of PSP toxin profiles during different growth phases in Gymnodinium catenatum (Dinophyceae) strains isolated from three locations in the Gulf of California, Mexico. J. Phycol. 2006, 42, 757-768.

10. Cembella, A.D.; Lewis, N.I.; Shumway, S.E. An interspecific comparison of paralytic shellfish poisons in marine bivalves: Anatomical and spatio-temporal variation in toxin composition. J. Shellfish Res. 1993, 12, 389-403.

11. Bricelj, M.V.; Shumway, E.S. Paralytic shellfish toxins in bivalve mollusks: Occurrence, transfer kinetics, and biotransformation. Rev. Fish. Sci. 1998, 6, 315-383.

12. Weise, M.; D’Angostino, P.M.; Mihali, T.K.; Moffitt, M.C.; Neilan, B.A. Neurotoxic alkaloids: Saxitoxin and its analogs. Mar. Drugs 2010, 8, 2185-2211.

13. Mons, M.N.; van Egmond, H.P.; Speijers, G.J.A. Paralytic Shellfish Poisoning: A Review; RIVM Report 388802; National Institute of Public Health and the Environment: Bilthoven, The Netherlands, 1998. 
14. Kao, C.Y.; Suzuki, C.Y.; Kleinahus, T.; Siegman, M.J. Vasomotor and respiratory depressant actions of tetrodotoxin and saxitoxin. Arch. Int. Pharmacodyn. 1967, 165, 438-450.

15. Evans, M.H. Cause of death in experimental paralytic shellfish poisoning. Br. J. Exp. Pathol. 1965, 46, 245-253.

16. Lagos, N. Paralytic shellfish poisoning phycotoxins: Occurrence in South America. Comments Toxicol. 2003, 9, 175-193.

17. INP-SAGARPA. Registro de mareas rojas en el Pacífico Sur de 1985 a 2004; Juárez-Ruiz, N., Ramírez-Camarena, C.; Barón-Campis, S.A., Eds.; Dirección General de Investigaciones Pesqueras Pacífico Sur, Instituto Nacional de la Pesca, Secretaría de Agricultura, Ganadería, Desarrollo Rural, Pesca y Alimentación: Ensenada, Mexico, 2004. Available online: http://fans.cic ese.mx/publicaciones/noticias/Cuadro\%20Mareas\%20Rojas\%20Pacifico\%20Sur-SEMARNAT.xls (accessed on 26 April 2012).

18. Shumway, S.E. A review of the effects of algal blooms on shellfish and aquaculture. J. World Aquac. Soc. 1990, 21, 65-104.

19. Lagos, N. Microalgal blooms: A global issue with negative impact in Chile. Biol. Res. 1998, 31, 375-386.

20. Moroño, A.; Franco, F.; Miranda, M.; Reyero, M.I.; Blanco, J. The effect of mussel size, temperature, volume, food quality, and volume-specific toxin concentration on the uptake rate of PSP toxins by mussels (Mytilus galloprovincialis). J. Exp. Mar. Biol. Ecol. 2001, 257, 117-132.

21. Gainey, L.F.; Shumway, S.E. A compendium of the responses of bivalve mollusks to toxic dinoflagellates. J. Shellfish Res. 1988, 7, 623-628.

22. Bricelj, V.M.; Cembella, A.D.; Lavy, D.; Shumway S.E.; Cucci, T.L. Comparative Physiological and Behavioral Responses to PSP Toxins in Two Bivalve Mollusks, the Soft Shell Clam, Mya arenaria, and Surf Clam, Spisula solidissima. In Harmful and Toxic Algal Blooms; Yasumoto, T., Oshima, Y., Fukuyo, Y., Eds.; UNESCO: Paris, France, 1996; pp. 405-408.

23. Matsuyama, Y.; Uchida, T.; Honjo, T. Effects of harmful dinoflagellates, Gymnodinium mikimotoi and Heterocapsa circularisquama, red-tide on filtering rate of bivalve molluscs. Fish. Sci. 1999, 65, 248-253.

24. Blanco-Pérez, J. Episodios Nocivos Por Fitoplancton. In Los Moluscos Pectínidos de Iberoamérica: Ciencia y Acuicultura; Maeda-Martínez, A.N., Ed.; Limusa: Mexico City, Mexico, 2001; pp. 285-324.

25. Estrada, N.A.; Lagos, N.; García, C.; Maeda-Martínez, A.N.; Ascencio, F. Effects of the toxic dinoflagellate Gymnodinium catenatum on uptake and fate of paralytic shellfish poisons in the pacific giant lions-paw scallop Nodipecten subnodosus. Mar. Biol. 2007, 151, 1205-1214.

26. Estrada, N.; Romero, M.J.; Campa-Córdova, A.; Luna, A.; Ascencio, A. Effects of the toxic dinoflagellate, Gymnodinium catenatum on hydrolytic and antioxidant enzymes, in tissues of the giant lions-paw scallop Nodipecten subnodosus. Comp. Biochem. Physiol. Part C 2007, 146, $502-510$.

27. Tran, D.; Haberkorn, H.; Soudant, P.; Ciret, P.; Massabuau, J.C. Behavioral responses of Crassostrea gigas exposed to the harmful algae Alexandrium minutum. Aquaculture 2010, 298, $338-345$. 
28. Haberkorn, H.; Tran, D.; Massabuau, J.C.; Ciret, P.; Savar, V.; Soudant, P. Relationship between valve activity, microalgae concentration in the water and toxin accumulation in the digestive gland of the Pacific oyster Crassostrea gigas exposed to Alexandrium minutum. Mar. Pollut. Bull. 2011, 62, 1191-1197.

29. Hégaret, H.; Wikfors, G.H.; Soudant, P.; Lambert, C.; Shumway, S.E.; Bérard, J.B.; Lassus, P. Toxic dinoflagellates (Alexandrium fundyense and A. catenella) have minimal apparent effects on oyster hemocytes. Mar. Biol. 2007, 152, 441-447.

30. Estrada, N.; Rodríguez-Jaramillo, C.; Contreras, G.; Ascencio, F. Effects of induced paralysis on hemocytes and tissues of the giant lions-paw scallop by paralyzing shellfish poison. Mar. Biol. 2010, 157, 1401-1415.

31. Hégaret, H.; Wikfors, G.H.; Shumway, S.E. Diverse feeding responses of five species of bivalve mollusc when exposed to three species of harmful algae. J. Shellfish Res. 2007, 26, 549-559.

32. Lesser, M.P.; Shumway, S.E. Effects of toxic dinoflagellates on clearance rates and survival in juvenile bivalve mollusks. J. Shellfish Res. 1993, 12, 377-381.

33. Lassus, P.; Ledoux, M.; Bohec, M.; Murail, I.; Fremy, J.M. Role of kidneys in bioaccumulation of paralytic toxins by scallop (Pecten maximus) tissues. J. Nat. Toxins 1996, 1, 107-115.

34. Shumway, S.E.; Cucci, T.L. The effect of the toxic dinoflagellate Protogonyaulax tamarensis on the feeding behavior of bivalve molluscs. Aquat. Toxicol. 1987, 10, 9-27.

35. Oshima, Y.; Sugino, K.; Itakura, H.; Hirota, M.; Yasumoto, T. Comparative Studies on Paralytic Shellfish Toxin Profile of Dinoflagellates in Bivalves. In Toxic Marine Phytoplankton; Graneli, E., Sundstrom, B., Edler, L., Anderson, D., Eds.; Elsevier: New York, NY, USA, 1990; pp. 391-396.

36. Suzuki, Y.; Yamasaki, M.; Ota, H. Comparison of paralytic shellfish toxin profiles between the scallop Patinopecten yessoensis and the mussel Mytilus galloprovincialis. Fish. Sci. 1998, 64, $850-851$.

37. Hall, S.; Strichartz G.; Moczydlowski, E.; Ravindran, A.; Reichardt, P.B. The Saxitoxins: Sources, Chemistry and Pharmacology. In Marine Toxins; Hall, S., Strichartz, G.R., Eds.; American Chemical Society Symposium Series 418; American Chemical Society: Washington, DC, USA, 1990; pp. 29-65.

38. Lehane, L. Paralytic Shellfish Poisoning: A Review; National Office of Animal and Plant Health, Agriculture, Fisheries and Forestry: Canberra, Australia, 2000.

39. Gárate, L.I.; Bustillos, J.J.; Alonso, R.R.; Luckas, D. Comparative paralytic shellfish toxins profile in two marine bivalves during outbreaks of Gymnodinium catenatum (Dinophyceae) in the Gulf of California. Mar. Pollut. Bull. 2004, 48, 378-402.

40. Fast, D.M.; Cembella, D.A.; Ross, W.N. In vitro transformation of paralytic shellfish toxins in the clams Mya arenaria and Protothaca staminea. Harmful Algae 2005, 191, 1-12.

41. Jaime, E.; Gerdts, G.; Luckas, B. In vitro transformation of PSP toxins by different shellfish tissues. Harmful Algae 2007, 6, 308-316.

42. Shumway, S.E.; Cucci, T.L.; Lesser, M.P.; Bourne, N.; Bunting, B. Particle clearance and selection in three species of juvenile scallops. Aquac. Int. 1997, 5, 89-99.

43. Brillant, M.G.S.; MacDonald, B.A. Postingestive selection in the sea scallop (Placopecten magellanicus) on the basis of chemical properties of particles. Mar. Biol. 2002, 141, 457-465. 
44. Newell, R.I.E.; Jordan, S.J. Preferential ingestion of organic material by the American oyster Crassostrea virginica. Mar. Ecol. Prog. Ser. 1983, 13, 47-53.

45. Negri, A.; Stirling, D.; Quilliam, M.; Blackburn, S.; Bolch, C.; Burton, I.; Eaglesham, G.; Thomas, K.; Walter, J.; Willis, R. Three novel hydroxybenzoate saxitoxin analogues isolated from the dinoflagellate Gymnodinium catenatum. Chem. Res. Toxicol. 2003, 16, 1029-1033.

46. Llewellyn, L.; Negri, A.; Quilliam, M. High affinity for the rat brain sodium channel of newly discovered hydroxybenzoate saxitoxin analogues from the dinoflagellate Gymnodinium catenatum. Toxicon 2004, 43, 101-104.

47. Negri, A.P.; Bolch, C.J.S.; Geier, S.; Green, D.H.; Park, T.-G.; Blackburn, S.I. Widespread presence of hydrophobic paralytic shellfish toxins in Gymnodinium catenatum. Harmful Algae 2007, 6, 774-780.

48. Vale, P. Complex profiles of hydrophobic paralytic shellfish poisoning compounds in Gymnodinium catenatum identified by liquid chromatography with fluorescence detection and mass spectrometry. J. Chromatogr. A 2008, 1195, 85-93.

49. Bustillos-Guzmán, J.; Vale, P.; Band-Schmidt, C. Presence of benzoate type toxins in Gymnodinium catenatum Graham isolated from the Mexican Pacific. Toxicon 2011, 57, 922-926.

50. Seki, T.; Satake, M.; Mackenzie, L.; Kaspar, H.F.; Yasumoto, T. Gymnodimine, a new marine toxin of unprecedented structure isolated from New Zealand oysters and the dinoflagellate, Gymnodinium sp. Tetrahedron Lett. 1995, 36, 7093-7096.

51. Miles, C.O.; Wilkins, A.L.; Stirling, D.J.; MacKenzie, A.L. New Analogue of Gymnodimine from a Gymnodinium species. J. Agric. Food Chem. 2000, 48, 1373-1376.

52. Stirling, D.J. Survey of historical New Zealand shellfish samples for accumulation of gymnodimine. N. Z. J. Mar. Freshw. Res. 2001, 35, 851-857.

53. Biré, R.; Krys, S.; Frémy, J.M.; Dragacci, S.; Stirling, D.J.; Kharrat, R. First evidence on occurrence of gymnodimine in clams from Tunisia. J. Nat. Toxins 2002, 11, 269-275.

54. Emura, A.; Matsuyama, Y.; Oda, T. Evidence for the production of a novel proteinaceous hemolytic exotoxin by dinoflagellate Alexandrium taylori. Harmful Algae 2004, 3, 29-37.

55. Arzul, G.; Seguel, M.; Guzman, L.; Erard-Le Denn, E. Comparison of allelopathic properties in three toxic Alexandrium species. J. Exp. Mar. Biol. Ecol. 1999, 232, 285-295.

56. Tillmann, U.; Alpermann, T.; John, U.; Cembella, A. Allelochemical interactions and short-term effects of the dinoflagellate Alexandrium on selected photoautotrophic and heterotrophic protists. Harmful Algae 2007, 7, 52-64.

57. Lush, G.J.; Hallegraeff, G.M.; Munday, B.L. High Toxicity of the Red Tide Dinoflagellate Alexandrium minutum to the Brine Shrimp Artemia salina. In Harmful and Toxic Algal Blooms; Yasumoto, T., Oshima, Y., Fukuyo, Y., Eds.; UNESCO: Paris, France, 1996; pp. 389-392.

58. Bagoien, E.; Miranda, A.; Reguera, B.; Franco, J.M. Effects of two paralytic shellfish toxin producing dinofagellates on the pelagic harpacticoid copepod Euterpina acutifrons. Mar. Biol. 1996, 126, 361-369.

59. Brillant, M.G.S.; MacDonald, B.A. Postingestive selection in the sea scallop, Placopecten magellanicus (Gmelin): the role of particle size and density. J. Exp. Mar. Biol. Ecol. 2000, 253, 211-227. 
60. Beecham, J. Literature Review on Particle Assimilation by Molluscs and Crustaceans; Cefas Contract C2706; The Centre for Environment, Fisheries and Aquaculture Science: Lowestoft, UK, 2008; p. 19.

61. Cheng, T. Bivalves. In Invertebrate Blood Cells; Ratcliffe, N.A., Rowley, A.F., Eds.; Academic Press: New York, NY, USA, 1981; pp. 233-300.

62. Fisher, W.S. Structure and Functions of Oyster Hemocytes. In Immunity in Invertebrates; Brehélin, M., Ed.; Springer Verlag: Berlin, Germany, 1986; pp. 25-35.

63. Wikfors, G.H.; Smolowitz, R.M. Detrimental Effects of a Prorocentrum Isolate upon Hard Clams and Bay Scallops in Laboratory Feeding Studies. In Toxic Phytoplankton Blooms in the Sea, 1st ed.; Smayda, T.J., Shimizu, Y., Eds.; Elsevier: New York, NY, USA, 1993; pp. 447-452.

64. Beninger, P.G.; Le Pennec, M.; Donval, A. Mode of particle ingestion in five species of suspension-feeding bivalve molluscs. Mar. Biol. 1991, 108, 255-261.

65. Beninger, P.G.; Le Pennec, M. A histochemical study of the bucco-oesophageal glands of the blue mussel. Mytilus edulis L.: The importance of mucus in ingestion. J. Mar. Biol. 1993, 73, 237-240.

66. Pales, E.E.; Perrigault, M.; Ward, J.E.; Shumway, S.E.; Allam, B. Lectins associated with the feeding organs of the oyster Crassostrea virginica can mediate particle selection. Biol. Bull. 2009, 217, 130-141.

67. Vargas-Albores, F.; Barracco, M.A. Mecanismos de Defensa de los Moluscos Bivalvos, con Énfasis en Pectínidos. In Los Moluscos Pectínidos de Iberoamérica: Ciencia y Acuicultura; Maeda-Martínez, A.N., Ed.; Limusa: Mexico City, Mexico, 2001; pp. 127-146.

68. Hégaret, H.; Shumway, S.; Wikfors, G.; Pate, S.; Burkholder, J. Potential transport of harmful algae via relocation of bivalve molluscs. Mar. Ecol. Prog. Ser. 2008, 361, 169-179.

69. Galimany, E.; Sunila, I.; Hégaret, H.; Ramón, M.; Wikfors, G.H. Pathology and immune response of the blue mussel (Mytilus edulis L.) after an exposure to the harmful dinoflagellate Prorocentrum minimum. Harmful Algae 2008, 7, 630-638.

70. Bricelj, V.M.; Lee, J.H.; Cembella, A.D. Influence of dinoflagellate cell toxicity on uptake and loss of paralytic shellfish toxins in the northern quahog Mercenaria mercenaria. Mar. Ecol. Prog. Ser. 1991, 74, 33-46.

71. Li, S.C.; Wang, W.X.; Hsieh, D.P.H. Effects of toxic dinoflagellate Alexandrium tamarense on the energy budgets and growth of two marine bivalves. Mar. Environ. Res. 2002, 53, 145-160.

72. Hwang, D.F.; Chueh, C.H.; Jeng, S.S. Susceptibility of fish, crustacean and mollusk to tetrodotoxin and paralytic shellfish poison. Nippon Suis. Gak. 1990, 56, 337-343.

73. Lu, Y.H.; Hwang, D.F. Effects of toxic dinoflagellates and toxin biotransformation in bivalves. J. Nat. Toxins 2002, 11, 315-322.

74. Bricelj, V.M.; Connell, L.; Konoki, K.; MacQuarrie, S.P.; Scheuer, T.; Catterall, W.A.; Trainer, V.L. Sodium channel mutation leading to saxitoxin resistance in clams increases risk of PSP. Nature 2005, 434, 763-767.

75. Haberkorn, H.; Lambert, C.; Le Goïc, N.; Moal, J.; Suquet, M.; Guéguen, M.; Sunila, I.; Soudant, P. Effects of Alexandrium minutum exposure on nutrition-related processes and reproductive output in oysters Crassostrea gigas. Harmful Algae 2010, 9, 427-439. 
76. Bricelj, V.M.; Lee, J.H.; Cembella, A.D.; Anderson, D.M. Uptake of Alexandrium fundyense by Mytilus edulis and Mercenaria mercenaria under Controlled Conditions. In Toxic Marine Phytoplankton; Graneli, E., Sundstrom, B., Edler, L., Anderson, D.M., Eds.; Elsevier Science: New York, NY, USA, 1990; pp. 269-275.

77. Connell, L.B.; MacQuarrie, S.P.; Twarog, B.M.; Iszard, M.; Bricelj, M. Population differences in nerve resistance to paralytic shellfish toxins in softshell clam, Mya arenaria, associated with sodium channel mutations. Mar. Biol. 2010, 150, 1227-1236.

78. Hummert, C.; Riutscher, M.; Reinhardt, K.; Luckas, B. Analysis of characteristic PSP profiles produced by Pyrodinium bahamense and several strains of Alexandrium using HPLC based on ion-pair chromatographic separation, post column oxidation and fluorescence detection. Chromatographia 1997, 45, 312-316.

79. Yu, R.C.; Hummert, C.; Luckas, B.; Qian, P.Y.; Zhou, M.J. A modified HPLC method for analysis of PSP toxins in algae and shellfish from China. Chromatographia 1998, 48, 671-676.

80. Raymond, W.M.K.; Weng-Xiong, W.; Paul, K.S.L.; Peter, K.N.Y. The uptake, distribution and elimination of paralytic shellfish toxins in mussels and fish exposed to toxic dinoflagellates. Aquat. Toxicol. 2006, 80, 82-91.

81. Oshima, Y. Chemical and Enzymatic Transformation of Paralytic Shellfish Toxins in Marine Organisms. In Harmful Marine Algal Blooms; Lassus, P., Arzul, G., Erard, E., Gentien, P., Marcaillou, C., Eds.; Technique et Documentation-Lavoisier, Intercept: Paris, France, 1995; pp. 475-480.

82. Doucette, G.; Maneiro, I.; Riveiro, I.; Svensen, C. 22 Phycotoxin pathways in aquatic food webs: Transfer, accumulation and degradation. Ecol. Harmful Algae 2006, 189, 283-295.

83. Shimizu, Y.; Yoshioka, M. Transformation of paralytic shellfish toxins as demonstrated in scallop homogenates. Science 1981, 212, 547-549.

84. Sullivan, J.J.; Iwaoka, W.T.; Liston, J. Enzymatic transformation of PSP toxins in the littleneck clam (Protothaca staminea). Biochem. Biophys. Res. Commun. 1983, 114, 465-472.

85. Murakami, R.; Yamamoto, K.; Noguchi, T. Toxicity and paralytic shellfish poison composition of three species of bivalves collected in Ibaraki Prefecture, Japan. J. Food Hyg. Soc. Jpn. 1999, $40,46-54$.

86. Cho, Y.; Ogawa, N.; Takahashi, M.; Lin, P.H.; Oshima, Y. Purification and characterization of paralytic shellfish toxin-transforming enzyme, sulfocarbamoylase I, from the Japanese bivalve Peronidia venulosa. Biochim. Biophys. Acta 2008, 1784, 1277-1285.

87. Cembella, D.A.; Shumway, E.S.; Larocque, R. Sequestering and putative transformation of paralytic shellfish toxins by the sea scallop Placopecten magellanicus: Seasonal and spatial scales in natural populations. J. Exp. Mar. Biol. Ecol. 1994, 180, 1-22.

88. Haya, K.; Martin, L.J.; Robinson, M.C.S.; Martin, D.J.; Khots, A. Does uptake of Alexandrium fundyense cysts contribute to the levels of PSP toxin found in the sea scallop, Planopecten magellanicus? Harmful Algae 2003, 2, 75-81.

89. Wong, K.C.; Hung, P.; Lee, L.H.K.; Mok, T.; Kam, M.K. Effect of steam cooking on distribution of paralytic shellfish toxins in different tissue compartments of scallops Patinopecten yessoensis. Food Chem. 2009, 114, 72-80. 
90. Jiang, T.; Niu, T.; Xu, X. Transfer and metabolism of paralytic shellfish poisoning from scallop (Chlamys nobilis) to spiny lobster (Panulirus stimpsoni). Toxicon 2006, 48, 998-994.

91. Band-Schmidt, C.J.; Bustillos-Guzmán, J.J.; López-Cortés, D.J.; Gárate-Lizárraga, I.; Núñez-Vázquez, E.J.; Hernández-Sandoval, F.E. Ecological and Physiological Studies of Gymnodinium catenatum in the Mexican Pacific: A review. Mar. Drugs 2010, 8, 1935-1961.

92. Morquecho, M.L.; Lechuga-Devéze, C.H. Dinoflagellates in recent sediments from Bahía Concepción, Gulf of California. Bot. Mar. 2003, 46, 132-141.

93. Gárate-Lizárraga, I.; Bustillos-Guzmán, J.J.; Alonso-Rodríguez, R.; Luckas, B. Comparative paralytic shellfish toxin profiles in two marine bivalves during outbreaks of Gymnodinium catenatum (Dinophyceae) in the Gulf of California. Mar. Pollut. Bull. 2004, 48, 378-402.

94. de la Garza-Aguilar, J. Intoxicación alimentaria por ingestión de mariscos contaminados. Salud Pública Méx. 1983, 25, 145-150.

95. Mee, L.D.; Ramírez-Flores, A.; Flores-Verdugo, F.; González-Frías, F. Coastal upwelling and fertility of the Southern Gulf of California: Impact of the 1982-83 ENSO event. Trop. Ocean Atmos. Newsl. 1985, 31, 9-10.

96. Morey-Gaines, G. Gymnodinium catenatum Graham (Dinophyceae): Morphology and affinities with armoured forms. Phycologia 1982, 21, 154-163.

97. Hurst, J.W.; Gilfillan, E.S. Paralytic Shellfish Poisoning in Maine. In Proceedings of the 10th National Shellfish Sanitation Workshop, Hunt Valley, MD, USA, 29-30 June 1977; Wilt, D.S., Ed.; US Department of Health, Education and Welfare, Food and Drug Administration: Washington, DC, USA, 1977; pp. 152-161.

98. Oshima, Y.; Yasumoto, T.; Kodama, M.; Ogata, T.; Fukuyo, Y.; Matsuura, F. Features of paralytic shellfish poison occurring in Tohoku district. Nippon Suisan Gakkaishi 1982, 48, 525-530.

99. Takatani, T.; Morita, T.; Anami, A.; Akaeda, H.; Kamijyo, Y.; Tsutsumi, K.; Noguchi, T. Appearance of Gymnodinium catenatum in association with the toxification of bivalves in Kamae, Oita Prefecture, Japan. J. Food Hyg. Soc. Jpn. 1998, 39, 275-280.

100. Morquecho, E.L. Coleccion de dinoflagelados marinos CODIMAR. Centro de Investigaciones Biológicas del Noroeste, S.C. La Paz, B.C.S., México, 2008. Available online: http://www.cibnor. $\mathrm{mx} / \mathrm{es} /$ investigacion/colecciones-biologicas/codimar/entrada (accessed on 25 April 2012).

101. Doblin, M.; Blackburn, S.I.; Hallegraeff, G.M. Comparative study of selenium requirements of three phytoplankton species: Gymnodinium catenatum, Alexandrium minutum (Dinophyta) and Chaetoceros cf. tenuissimus (Bacyllariophyta). J. Plankton Res. 1999, 21, 1153-1169.

102. Rodríguez-Jaramillo, C.; Hurtado, M.A.; Romero-Vivas, E.; Ramírez, J.L.; Manzano, M.; Palacios, E. Gonadal development and histochemistry of the tropical oyster Crassostrea corteziensis (Hertlein, 1951) during an annual reproductive cycle. J. Shellfish Res. 2008, 27, 1129-1141.

(C) 2012 by the authors; licensee MDPI, Basel, Switzerland. This article is an open access article distributed under the terms and conditions of the Creative Commons Attribution license (http://creativecommons.org/licenses/by/3.0/). 